This is a self-archived - parallel published version of this article in the publication archive of the University of Vaasa. It might differ from the original.

\title{
Virtual enterprise collaborative processes monitoring through a project business approach
}

Author(s): Shamsuzzoha, Ahm; Helo, Petri; Sandhu, Maqsood

Title: $\quad$ Virtual enterprise collaborative processes monitoring through a project business approach

Year: $\quad 2017$

Version: Accepted manuscript

Copyright (C)2017 Taylor \& Francis. This is an Accepted Manuscript of an article published by Taylor \& Francis in International Journal of Computer Integrated Manufacturing on 10 Feb 2017, available online:

http://www.tandfonline.com/10.1080/0951192X.2017.1285427.

\section{Please cite the original version:}

Shamsuzzoha, A., Helo, P., \& Sandhu, M., (2017). Virtual enterprise collaborative processes monitoring through a project business approach. International Journal of Computer Integrated Manufacturing 30(10), 1093-1111. https://doi.org/10.108o/0951192X.2017.1285427 


\title{
Virtual enterprise collaborative processes monitoring through project business approach
}

\begin{abstract}
This paper presents a systematic approach to project business process monitoring and identifies the key aspects of virtual enterprise (VE) process evaluation. A framework for VE business processes monitoring is presented with special emphasis in linking interest groups to the development of their targets, information, and knowledge sharing. The proposed model defines the exclusive performance metrics, which are needed during business process monitoring. This interdisciplinary study examines business process monitoring through peer-to-peer information exchange in the VE domain, which is currently not sufficiently explained. The fundamental metrics to define business process performance monitoring are elaborated in this research study. The identified performance metrics can be used to measure the overall performances for both project business and virtual enterprise. In addition to reference architecture, a case example is presented to monitor business processes within project business virtual enterprise. An overall definition of collaborative business process monitoring and performance management systems is also presented accordingly. This research concludes with future research directions regarding the nature of collaboration in project business virtual enterprise and the characteristics of performance indicators to support it.
\end{abstract}

Keywords: Project business, virtual enterprise, process monitoring, information exchange, performance management, performance metrics and measurement. 


\section{Virtual enterprise process monitoring through project business approach}

\section{Introduction}

Project business refers to an operations mode, which is built on projects. Characteristic features of uniqueness, complexity, uncertainty and timeliness define the operations (Gustafsson et al. 2009; Sandhu 2005). Typically, engineering and complex dependencies between activities and technical systems play an important role. Organizational structures and vendors change in projects due to uniqueness factor. Timeliness and critical path dependency combined with time pressure also set a requirement for communication and process integration (Hobday 2000; Prencipe and Tell 2001; Blindenbach-Driessen and Ende 2010).

In such a changing environment, companies must look forward to execute their business processes in such a manner as to maximize the process efficiency (Holstius 1989; Tikkanen et al. 2007; Vergidis et al. 2015). To improve their processes efficiencies, companies need to move from internal information integration to information exchange with other companies (cooperation) and eventually to collaboration.

With the rapid development of Internet technology, more and more businesses have formed as virtual enterprises (Yang et al. 2015). This kind of collaboration promotes the formation of virtual enterprises that enable companies to achieve core competencies and practice lean manufacturing for economic benefit (Goranson 2003; Ouzizi et al. 2006). The virtual enterprise involves a number of partner companies that are mostly geographically distributed and of a similar kind of business. The term virtual enterprise implies that business processes are jointly derived, jointly executed and jointly measured throughout the collaboration stream (Ouzizi et al. 2006; Molina et al. 2007).

This paper focuses on the application of the virtual enterprise concept in project businesses. In other words, we are interested to know how virtual enterprises have developed their internal and external activities when doing project business in a network context. The research gap on adaptation of the virtual enterprise concept in project businesses is addressed and a framework is proposed for technical implementation. This research is structured as follows: Section 2 outlines the literature review on project business and virtual enterprises, whereas Section 3 states the comparison between project businesses versus virtual enterprise. Project business in terms of a virtual enterprise business environment describes in Section 4. Section 5 presents a framework for project business with virtual enterprises and defines their lifecycles, and Section 6 reviews performance management in a project based VE environment. A business process-monitoring framework to improve project-based VE management is presented in Section 7. In Section 8, a case example is highlighted, where project business VE process monitoring is demonstrated. The overall research outcomes and future work are outlined in the conclusion in Section 9.

\section{Literature review}

\subsection{Description of project business: a way towards improved coordination}

The term 'project business' is an evolving area within project management research that can be divided into two separate concepts namely, 'project' and 'business', which are integral parts for any organizations. A 'project' can be defined as the representation of various activities that are undertaken to improve coordination for fulfilling specific goals (Gunasekaran et al., 2001; Sandhu 
and Gunasekaran 2004; Brenen et al. 2004; Whitley 2006). On the other hand, a 'business' represents the strategic focus of an organization. In combination, project business provides an excellent understanding of various contextual features, where projects are conducted (Morris 1994; Turner and Keegan 2001). According to Artto and Wikstrom (2005), project business is defined as "the part of business that relates directly or indirectly to projects, with a purpose to achieve objectives of a firm or several firms".

In today's business environment, projects are brought to a strategic viewpoint; where interdependent multiple projects contribute to the fulfillment of specific goals in the entire business system (Cova and Holstius 1993; Shenhar and Dvir 2004, Artto and Wikstrom 2005; Wikstrom et al. 2010). In the context of strategic management, project business addresses the characteristics of strategy formulation and implementation from a project marketing perspective (McDonough and Spital 2003; Barrett and Sexton 2006). It emphasizes project portfolio management as giving enough recognition to the business contexts of projects, such as strategic, business cycle and research and development (Lycett et al. 2004; Xue et al. 2010). Strategy is an important issue in project business as it is intrinsically associated with the organization and its goals.

The characteristics of project business is that it is specifically related to context, timelimitedness, value creation properties, type of complexity and its high degree of uncertainty and limited possibilities for standardization (Hellström 2005; Thiry and Deguire 2007). To cope with different business challenges such as increased outsourcing, technological convergence, solutions in information and communication technologies, digitalization, etc., organizations are moving towards adopting project-based business, which enables them to interact with each other. This multi-organization network offers the possibility of overcoming the challenges caused by project discontinuity, there is a 'no project' phase or 'sleeping phase' between two delivery projects (Hadjikhani 1996; Cova et al. 2002).

In general, a multi-organization business network represents a dynamic context for firms and projects, which are characterized by various business interests. Such a business network should be efficient and effective in order to get better results (Harmon 2015)). In this context, it is necessary to monitor this type of business network to measure its overall performance. This performance measurement is also relevant for obtaining a perspective across collaborative firms in the business network (Kujala et al. 2007). Performance monitoring within a business network minimizes possible risks and uncertainty in doing project-based business (Ariyachandra and Frolick 2008).

\subsection{Description of the virtual enterprise: an approach towards collaborative business}

In order to respond promptly to global business challenges, companies are adopting various strategies such as make or buy, coalition, merger and acquisition, co-creation, collaboration, etc. Keeping these business strategies in mind, companies are nowadays moving towards working together with the objective of developing inter-firm collaboration, where groups of autonomous companies agree to contribute with knowledge and resources to joint actions to achieve common objectives (Valilai and Houshmand 2014). This kind of collaboration can be referred to as virtual enterprise (MacCarthy, B.L. and Ramanathan 2007; Bondar et al. 2014).

Internet technology plays an important role in the formation and execution of such an enterprise. This enterprise operates virtually in combining several independent companies that are physically distributed globally (Chen et al. 2013). The nature of such an enterprise is mainly establishing online-based communication channels to support the monitoring and management of its every activity remotely. That is why this kind of enterprise is mainly orchestrated through 
various types of sensor-enabled technologies and tools to support its operational activities (Varela et al. 2012; Zhang et al. 2015).

Although various smart technologies and tools mainly operate the virtual enterprise remotely, often it also needs a physical presence (Le at al. 2015). For instance, if anything goes wrong in any of its operations, personnel from the broker company that initiates and maintains this enterprise need to be physically present there to find, instruct and solve the problem. This special form of enterprise is growing in popularity within manufacturing communities for its accompanying benefits (Cao et al. 2009; Panetto and Cecil 2013).

In line with this, such an enterprise explores business collaborations that are normally the result of negotiations based on mutual trust and based on hierarchy architectures Shamsuzzoha et al. 2012). Such types of collaboration need to evaluate performance based on several pre-identified metrics. This performance measurement approach refers to a predictive performance approach, where an explicit model of the system is used to control and to predict future output behavior, taking into account the virtual network environment and its participants. In addition to such benefit, this performance approach makes it possible to support collaborative decision makers in making decisions that are more accurate in a more proactive way (Camarinha- Matos and Abreu 2007; Ferreira et al. 2014).

\subsection{Research gaps towards project business virtual enterprise process monitoring for mutual benefits}

It is found from the state-of-the-art literature review that there are different kinds of business collaboration exist within global business environment. Although such collaborations are termed as differently but the basic objectives are to get business benefits by collaborating with one partner organization with other one. The names of such business collaborations can be as business ecosystem (Gossain and Kandiah, 1998), industry cluster (Feser and Bergman, 2000), collaborative network organization (Camarinha-Matos et al., 2007), virtual organization (Mowshowitz, 1994), virtual organization breeding environment (VBE) (Camarinha-Matos and Afsarmanesh, 2005; Romero and Molina, 2010), business community (Carneiro et al., 2010), virtual factory (Jain et al., 2001), etc.

Based on the collaboration types, different process monitoring and management frameworks are developed with the objective to measure collaborative processes performances. For instance, Bullinger et al. (2002) presented a hybrid balanced performance monitoring system for network of enterprises by integrating both SCOR model (Supply Chain Operations Reference) and adapted balanced scorecards. The concept of Meta-performance monitoring as proposed by Lescure et al. (2001) describes the performance at the business network level. A performance monitoring and management system is highlighted by Saiz et al. (2005) to control and monitor efficiently the performance for virtual and extended enterprises. Romero and Molina (2010) proposed a VBE reference model to execute and monitor VBE processes. Ferreira et al. (2012) presented a virtual organization performance monitoring framework to monitor different business processes. Schulte et al. (2012) outlined a virtual factory process monitoring framework by integrating serviceoriented computing, Internet of Things and business process management system.

The new concept 'project business VE' as introduced in this research also needs to monitor and measure performance its collaborative processes. This research gap is identified and focused in this research study. With the objective to monitor and measure performance in project business $\mathrm{VE}$, a reference architecture is introduced. This reference architecture is consisted of three sections 
namely, performance levels, performance dimensions and performance framework. Details of the reference architecture is explained in Section 6.

\section{Comparison of project business versus virtual enterprise}

Project business can be termed as a business environment, where a set of interrelated tasks to be executed over a fixed period and within specified budget and other constraints (Sandhu and Gunasekaran, 2004). This business strategy goes beyond traditional organizational boundaries, where the business environment focuses on its core business and technical activities and outsources non-core business activities. It integrates all parts of organizations such as customers, suppliers, sub-contractors, etc., and engaged them in design, development, production and delivery phases of a product. It is therefore, essential to establish an information and communication technology (ICT) based communication framework to support such kind of business strategy. In addition to ICT support, it is also important to have maximum degree of compatibility among business partners IT systems.

On the other hand, the virtual enterprise (VE) is generally a temporary organization, where independent and individual partner organization collaborate with each other to exploit specific business opportunity. Such form of VE, all partners cooperate themselves based on costeffectiveness and product uniqueness without considering the size and geographical location. All partners retain their independence, access to a wide range of specialized resources and continue to improve their core competencies within this collaborative network. Such sharing of resources, skills, cost and core competencies enable them to access global markets collectively, which might not be provided by any one of the individual partner organization (Carneiro et al., 2010). Within the virtual enterprise the partners are integrated using information and communication technology. It can also be a network of creative people connected via online services, bulletin board and the Internet. It is a flat organization, where every partner is an owner of the enterprise and directly contributes to its success or failure (Browne and Zhang, 1999).

Project business is mostly based on mutually dependent relationships between partners with maintaining of long-term trust, while a virtual enterprise consists of independent partners with temporary trust and relationships. Clearly, the project business and virtual enterprise paradigms share many determinants, but they also differ in some important points. Such differences can be identified based on several determinants such as collaboration type, decision-making, organization structure, business strategy, characteristics, partnerships style, information sharing, collaboration objective, resources, communication pattern, competency and activity monitoring. These determinants are used to clearly differentiate between project business and virtual enterprise as presented in Table 1.

Table 1. A comparison of the project business and virtual enterprise with various determinants (adapted from Browne and Zhang, 1999).

\begin{tabular}{|l|l|l|}
\hline Determinants & Project business & Virtual enterprise \\
\hline Collaboration type & $\begin{array}{l}\text { Long-term business cooperation } \\
\text { and trust }\end{array}$ & $\begin{array}{l}\text { Short-term business cooperation and } \\
\text { trust }\end{array}$ \\
\hline Decision making & Project manager & VE broker \\
\hline $\begin{array}{l}\text { Organization } \\
\text { structure }\end{array}$ & Mainly hierarchical partnership & Non-hierarchical partnership \\
\hline Business strategy & Value-chain based & Niche market based \\
\hline
\end{tabular}




\begin{tabular}{|l|l|l|}
\hline Characteristics & $\begin{array}{l}\text { Single or multiple project, } \\
\text { dynamic nature }\end{array}$ & $\begin{array}{l}\text { Multiple companies, temporary } \\
\text { nature }\end{array}$ \\
\hline Partnerships style & Long-term mutual dependence & Temporary and dynamic dependence \\
\hline Information sharing & Transparent, seamless & Fast and accurate \\
\hline $\begin{array}{l}\text { Collaboration } \\
\text { objective }\end{array}$ & $\begin{array}{l}\text { Product value chain based, } \\
\text { integrated, long-term }\end{array}$ & $\begin{array}{l}\text { Project-based, coordinated, short- } \\
\text { term, niche market opportunity based }\end{array}$ \\
\hline Resources & Generic & Specialized \\
\hline $\begin{array}{l}\text { Communication } \\
\text { pattern }\end{array}$ & $\begin{array}{l}\text { Enabled by ICTs, time } \\
\text { dependent information update }\end{array}$ & $\begin{array}{l}\text { Web-based platform, real-time } \\
\text { information update }\end{array}$ \\
\hline Competency & Generic & Core, sophisticated \\
\hline Activity monitoring & Gantt chart, S curve & Web-based platform, smart objects \\
\hline
\end{tabular}

Although there are several characteristics matched between project business and virtual enterprise, but they also differ from each other in some important respects. The key differences can be summarized up and presented as follows:

- The project business environment is based on long-term partnership with established trust and mutually dependent relationships between partners, whereas, the partners within VE creates temporary relationships among partners with the objective to create new products and services.

- In case of project business environment, the manufacturing company focuses on its core skills and technical capabilities and outsources non-core business activities to suppliers based on their competitive abilities and skills, while VE shares core-competencies among partners through building trust and non-disclosure agreement.

- The focus of the project business is mainly on the product value chain, whereas, VE is frequently project-based which depends on identified business opportunity.

- In VE business model, product's time to market is greatly reduced through real-time information exchange between collaborating partners, while in project business time to market is reduced through quick response manufacturing with integrated product design and manufacturing from all the project participants.

- In project business, essential methods, business processes and technologies are usually available in order to conduct business activities, whereas, in VE everything are started from scratch and reconfigured based on collaboration requirements.

In summary, project business and VE business models can be seen as two complementary manufacturing strategies. In fact, both models pursue business partnerships with the objective to achieve business success in today's very competitive market segment. The major difference between two models mainly lies in time strap. Project business offers relative stability, while VE is in the temporary nature. The VE usually seen as a platform, where partner organizations getting together to produce a product or service quickly for the market to fulfill specific customers' requirements. To maintain efficient relationships among partners, the VE depends on high technology and advanced information systems. On the other hand, project business is relatively maintain organizational stability and maintains relationships across the value chain.

\section{Project business as virtual enterprises}

Project business has been one of the dominating modes of international business for the past sixty years, and its prevalence continues to increase. More than $60 \%$ of exports from Finland and Sweden are in the form of project business, and the proportion is similar in other developed 
countries (Artto et al. 1998; Hadjikhani 1996; Steinthórsson 2003). As Bryde (2000) has observed: "the need to survive and prosper in ever-changing external environments is the most important driver behind the growth in project management". The reason for such growth is the customers' demand for customized products, competitive prices, and prompt delivery. Since the major characteristics of project businesses are: (i) uniqueness, (ii) complexity, and (iii) discontinuity, therefore, virtual enterprises play a major role in the delivery of a project or product. A project is unique in the sense that every project differs from others in size, type, customers, suppliers, volume, price, and so on. It is complex in terms of the technical, financial, political, and social factors involved. Finally, it is discontinuous in terms of the high degree of discontinuity in economic relations between suppliers and the customers who are located in different geographical areas around the globe. Hence, virtual enterprises play a vital role in the development of such business. However, monitoring their process and performance is challenging.

The term 'project business' denotes the overall activities of a project company that creates and delivers projects to its customers. The supplier, for its part, takes more responsibility for the success of a project than it would if supplying only some components or merely exporting some parts. As there are many business networks, hierarchical and non-hierarchical networks, internal and external networks in existence, project business is thus an interaction of inter-organizational and intra-organizational activities and their structures with respect to marketing, planning, procuring, and executing project activities (Han et al. 2015). Davies and Hobday (2005) use the term project business to refer to organizations "which may be entire enterprises or units within an enterprise - that deploy projects to achieve major business objectives, including all firms which design and produce complex products and systems (CoPS)".

For the purposes of this study, project business is defined broadly to encompass all business functions in which network actors and other stakeholders are involved in the process. These functions can be defined along the life cycle of a project as 'management', 'customer interface' (or 'concept development'), 'engineering', 'supply and procurement', 'transportation and logistics', 'construction', and 'operation'. In all of these activities, intra-organizational processes interact with inter-organizational processes throughout the project life cycle.

The term 'process' is an important concept that has received much attention and has received many interpretations from various perspectives (Child et al. 1994; Harrison 1995). Harrington (1991) defined process as, "the transformation of inputs into outputs; the inputs can be resources or requirements, whilst the outputs can be products or results. The output may or may not add value and could be an input to other process". When the above concept is applied commercially, both within an organization and between organizations, it is referred to as 'business process'. There are several definitions used in the literature in describing the design and the management of a business process. Tinnila (1995) stated that a "business process is a group of logically related tasks that use the resources of the organization to provide the defined results in support of organizational objectives". Zhou and Chen (2008) define business process as "a set of interrelated activities that collectively accomplish specific business objectives and accordingly convert inputs into outputs with the utilization or consumption and incurred flow of human and physical resources, information, capital, etc.,".

The driving force for this study is the gap between the reality of the firms engaged in project business in a virtual enterprise environment and the available studies covering project management and process monitoring for the development of project business. The effort is to elaborate some thoughts and views on how to manage the integration of virtual enterprises and manage the complexity and discontinuity of the projects, which interrelates the focal firms', inter- 
organizational and intra-organizational activities. In line with the integration, this research uses an approach to the management of project-business interdependencies in the networks of actors, activities and resources and delivery of the final product on time. The organizational functions of the focal actor, both inside and outside the enterprise, must be responsive to the dynamics of the market. This requires integration of the processes that interface with customers and suppliers (inter-organizational activities) and the support processes within the firm (intra-organizational activities). Such integration requires a framework to be developed and tested against the issues that arise for inter-organizational and intra-organizational management in virtual enterprises.

Demanding customer needs, new technologies, intensive competition, and changes in legislation mean that constant development is required in the environments of virtual enterprises and the management of their operations. The question is not whether companies should monitor and modify their processes, but how they can do so in a responsible, effective, and efficient manner.

In view of the above discussion, the overall research question addressed by this paper is therefore:

\section{How do virtual enterprises monitor their internal and external activities when doing project business in a network context?}

The first step in addressing this question is to establish the difference between project businesses and 'traditional' businesses. The organizations that are involved in project business are always formed around the activities involved. It is therefore appropriate to establish a structure for the processes involved in the key activities of project business. Establishing such a structure will allow a better understanding of how firms manage their internal and external activities when doing project business in a network context in a virtual environment.

Lundin and Steinthórsson (2003) have observed that projects are manifestations of organizational action, and that they thus provide interesting insights into the inner workings of a particular organization. Holmes (2001) suggested that modern managers focus more on the project team than managers did in the past. However, pressure from senior management to produce tangible results often causes managers to proceed directly to the implementation of processes without first establishing a solid foundation for understanding the inner workings of their business. Apart from understanding the internal workings of the organization, it is important to identify the external issues involved in project management - to understand their links and to manage the interdependencies of actors, activities, and resources and monitoring their processes in real time. The firm's internal and external actors drive the activities of the network and develop it in different directions, depending on the nature of the interdependencies that exist.

This study therefore presents a framework that is elaborated based on the reciprocal interactions of activities within and outside the organization, thus providing a coherent basis for continuous business process improvement in the virtual enterprise environment. In addition, the study presents new tools that can be used to develop project-business processes in each functional area in the intra-organizational context. The research demonstrates how project-business activities can be optimized using the right resources at the right time with the right actors and the right actions in an inter-organizational and intra-organizational perspective.

A business network is the involvement of two or more organizations in long-term relationships that position them as a 'mechanism' in markets and hierarchies. The central characteristic of a 
business network is that actors or organizations are embedded (Sandhu 2005) in interconnected social (and business) relationships that offer opportunities for, and constraints to, behavior.

In the context of project management, the present study understands a business network to be a group of geographically dispersed industries or a conglomerate of industries with disparate goals that perform the project activities using available resources to achieve the specific objective of the project in a virtual environment. These business networks are formed based on specific business areas within the project. However, each business area has its own set of internal and external relationships with customers, suppliers and partners - each in its own local market.

A project-virtual enterprise thus involves the cooperation of actors in a chain to construct a project of value for the end customer. This chain is integrally managed regarding organization, procedures, and technical systems. Virtual enterprises can be considered as the horizontal integration of core processes to handle each customer engagement with support processes, whereas vertical integration focuses on integrating and optimizing each separate business process.

With routine work, processes are usually carried out without any proper plan. Each individual knows his or her task within the enterprise and executes this task as efficiently as possible. However, in project business, customers do not judge firms by individual tasks; rather, they judge them based on the execution of overall business processes (and the eventual completion of the project or product). These processes require the cooperation and interdependencies of various people, resources and information. Insight into the entire chain of activities will uncover bottlenecks, and enable employees to anticipate and control these events themselves. This is why successful approaches to business development take a holistic view in which networks are perceived to be the starting-point.

Integrating all the internal and external processes is not an easy task because many organizations are involved, each with its own interests, and some might not share the common view. This can lead to significant divergences. Therefore, a commonly agreed model is essential in the implementation of business processes in a network context.

Business networks in the same industry and across industries tend to have varying levels of 'clusters' (Uzzi 1997; Sandhu 2005). These differences are due to organizations' attempts to maximize their status (that is, avoiding partners of lower status). In this paper, we argue that variability in this regard is a determinant of the level of relational 'embeddedness' in a business network. On occasions, business network ties can be weakened, or become dormant, because of this factor. Hence, in project business, a business network can be in a dormant mode for a specific period, but active when a business opportunity presents itself.

Business networks are influenced by the process requirements of virtual enterprises. Longitudinal studies have found that communication patterns change when organizations adopt new technologies (Burkhardt \& Brass 1990; Sandhu 2005; Sandhu and Ajmal 2010). In particular, recent changes in communication technology, such as electronic mail (email), have generated increased interest in the effects of technology on communication networks (Fulk and Steinfield 1990).

\section{Framework for project business with respect to virtual enterprise}

There are many similarities and differences between project business and virtual enterprise. An overall framework combining both project business and virtual enterprise can be highlighted as in Figure 1. The left part of Figure 1 highlights the systematic lifecycle of project business, while on 
the right side displays the lifecycle of the virtual enterprise. Although the steps are similar in both cases, in the objectives or scopes there are both similarities and dissimilarities.

Project based business is focused on long-term objectives and relationship with vendors, while virtual enterprise has short-term objectives with its partner organizations. Virtual organizations are formed based on identified business opportunities, while project business concentrates and defines its scope, and builds the team after an initial market survey. Both project business and virtual enterprise need to conduct monitoring to evaluate overall performance measures.

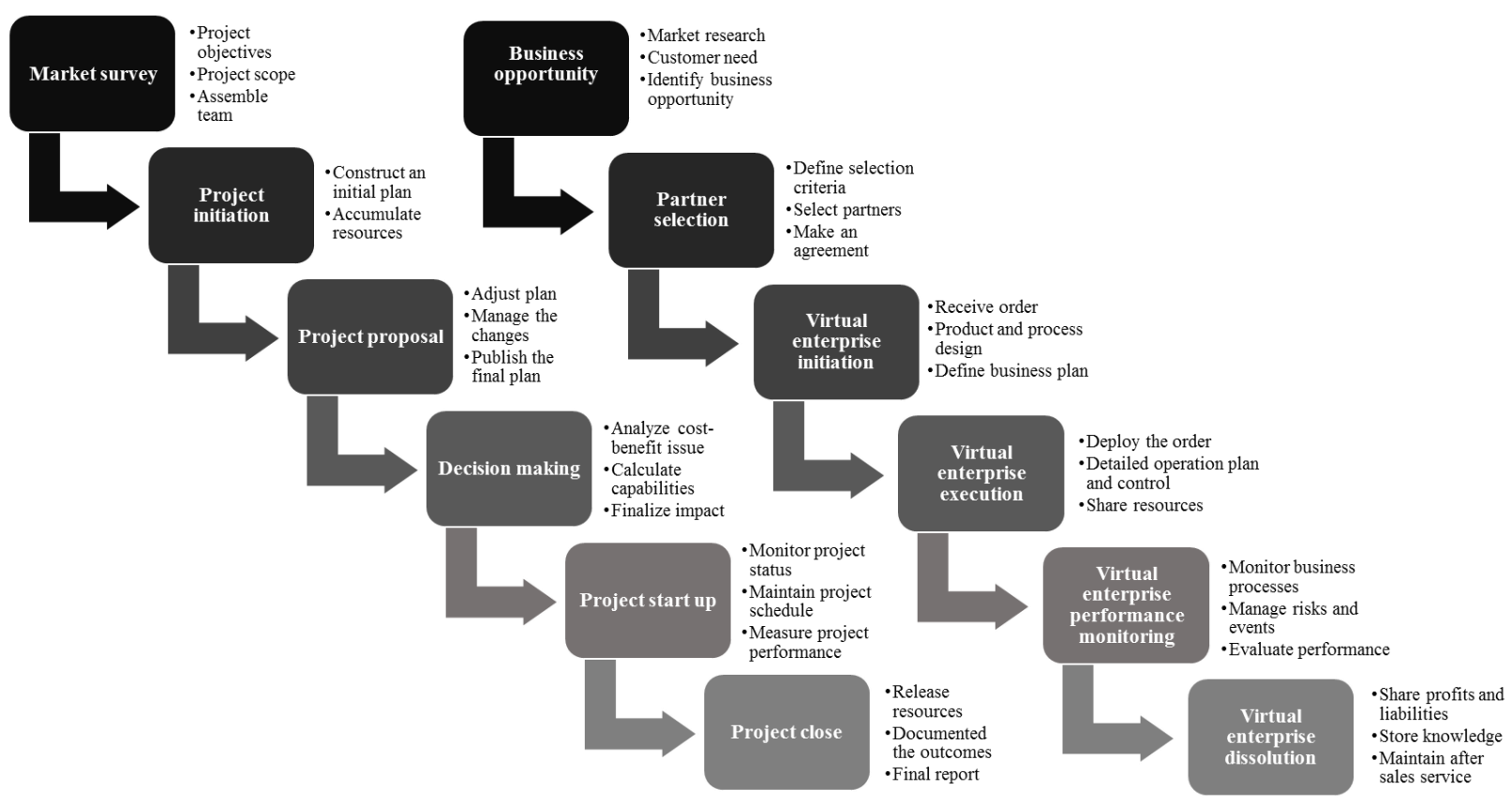

Figure 1. A framework for project business with respect to virtual enterprise.

From the perspective of project business lifecycle, it is noticed that there are six steps involved, namely market survey, project initiation, project proposal, decision making, project start up and project close. Each step of the project business life cycle has sub-phases, as seen in the Figure 1. For instance, the 'market survey' step has sub-phases of project objectives, project scope and assembly of the team, and so on.

The virtual enterprise life cycle has similarly six life cycle phases, namely business opportunity, partner selection, virtual enterprise initiation, virtual enterprise execution, virtual enterprise performance monitoring and virtual enterprise dissolution. Each of the phases has its own sub-phases. For example, the partner selection phase has sub-phases such as defining selection criteria, selecting partners and making an agreement.

\section{Performance management in project business virtual enterprises}

In order to measure the efficiency of a project business virtual enterprise, measuring its performance criteria is recommended. Generally, each of the developed project business virtual enterprises should have its own performance measurement system, part of which relates to its activities, which tend to be coordinated to ensure the necessary level of coordination and 
synchronization is achieved between individual enterprises (Kochhar and Zhang 2002). In fact, a project business virtual enterprise is a knowledge-based organization, and it uses the distributed capabilities, competencies and collaborative strengths of its partners to gain competitive advantage to maximize its overall performance. None of the performance measurement models and frameworks such as balanced scorecard, performance prism, IPMS, smart pyramid, etc. consider performance measurement and management from a project business virtual enterprise perspective.

Inter-enterprise partnership performance measures are essential for the benefit of executing effective and efficient virtual enterprise (Ferreira et al. 2012)). In such circumstances, this research work proposes a performance measurement and monitoring framework to measure the overall performance of a project business virtual enterprise. The focus of this research study is then concentrated on identifying various levels of project business VE performance levels, performance measurement framework with identified metrics, and overall performance management dimensions between project based organization and virtual enterprise.

\subsection{Performance measurement levels within a project business virtual enterprise}

In order to measure project business virtual enterprise performances correctly it is necessary to identify its various strategic levels. These levels are identified depending on the performances indices on each level. Figure 2 displays a performance measurement and management model within a project business VE, where different levels can be seen. From Figure 2, it is seen that the project business VE is divided into four levels: business process level, business unit level, enterprise level and collaboration level. Various performance measurement metrics in each level are also displayed in Figure 2.

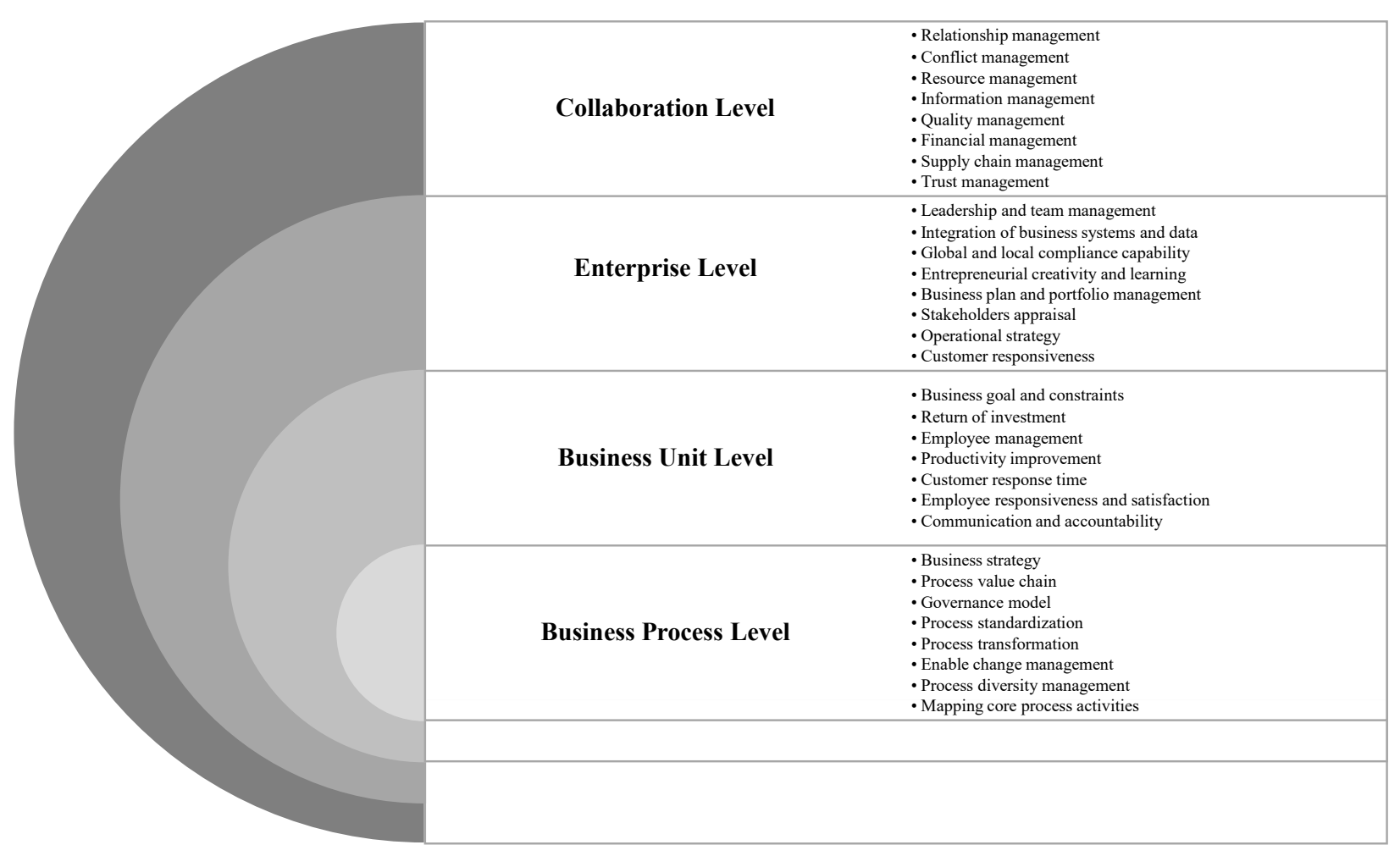


Figure 2. Different levels within project business VE's performance measurement and management model.

At the business process level, an individual component within a business process is measured to identify its performances. The performance metrics at this level can be identified as business strategy, process value chain, governance model, process standardization, process transformation, process diversity management, etc.

At the business unit level, each of the department or unit within an enterprise needs to be assessed based on its performance. Such performance metrics are directly involved to update or improve the current performance levels of each unit. Various performance indices at this unit level can be business goal and constraints, return on investment, resource management, productivity improvement, etc.

At enterprise level, where the performance metrics mainly depend on the integration management within various enterprises that are mutually integrated with other to effect benefits. The performance metrics at this level can be cooperation and collaboration, leadership and team management, integration of business systems and data, entrepreneurial creativity and learning, operational strategy, etc.

The final level of VE performance measurement and management model is collaboration level, where critical management issues are measured. The issues at this are level are measured as relationship management, conflict management, resource management, information management, trust management, financial management, quality management and supply chain management. The VE performance model highlighted in Figure 2 indicates that the overall performance of the VE fully depends on each level of VE. In general, performance metrics within the VE also depend on information types. These information types can be associated with product information, project level follow up, project execution follow up, project logistics and project quality records, as highlighted in Table 2. Table 2 shows that VE technological solutions are dependent on information types. For instance, product information can be obtained from a shared cloud-based product information system; product logistics information can be managed through logistics tracking and tracing information and site management software, etc.

Table 2. VE technological solutions based on information type.

\begin{tabular}{|l|l|}
\hline Information type & VE technological solution \\
\hline Product information & $\begin{array}{l}\text { Shared cloud based product information } \\
\text { system - BIM (building information system) } \\
\text { in constructions. }\end{array}$ \\
\hline Project level follow-up & Project portal with Gantt and s-curve \\
\hline Project execution follow-up & $\begin{array}{l}\text { Project portal with cloud-based information } \\
\text { repository }\end{array}$ \\
\hline Project logistics & $\begin{array}{l}\text { Tracking information and site management } \\
\text { software, } \\
\text { Batch number records }\end{array}$ \\
\hline Project quality records & $\begin{array}{l}\text { Change management system, } \\
\text { Quality records }\end{array}$ \\
\hline
\end{tabular}


Companies based on project business manage a portfolio of projects, which define the financial and operational performance. In the planning stage project, the work breakdown structure (WBS) is outlined and responsible partners are assigned for each task. One approach to manage the task schedule and resource allocation timeliness is to use a combination of Gantt chart and S-curve. By using these tools, a high-level comparison between planned and actual activities can be monitored (Figure 3).

Information should be updated frequently for project managers to follow up any deviations, as well as for all partners to see possible changes due to task dependencies. In a non-hierarchical network, information should not only be exchanged between contractor and sub-contractors, but also between sub-contractors, which might have a common interaction.

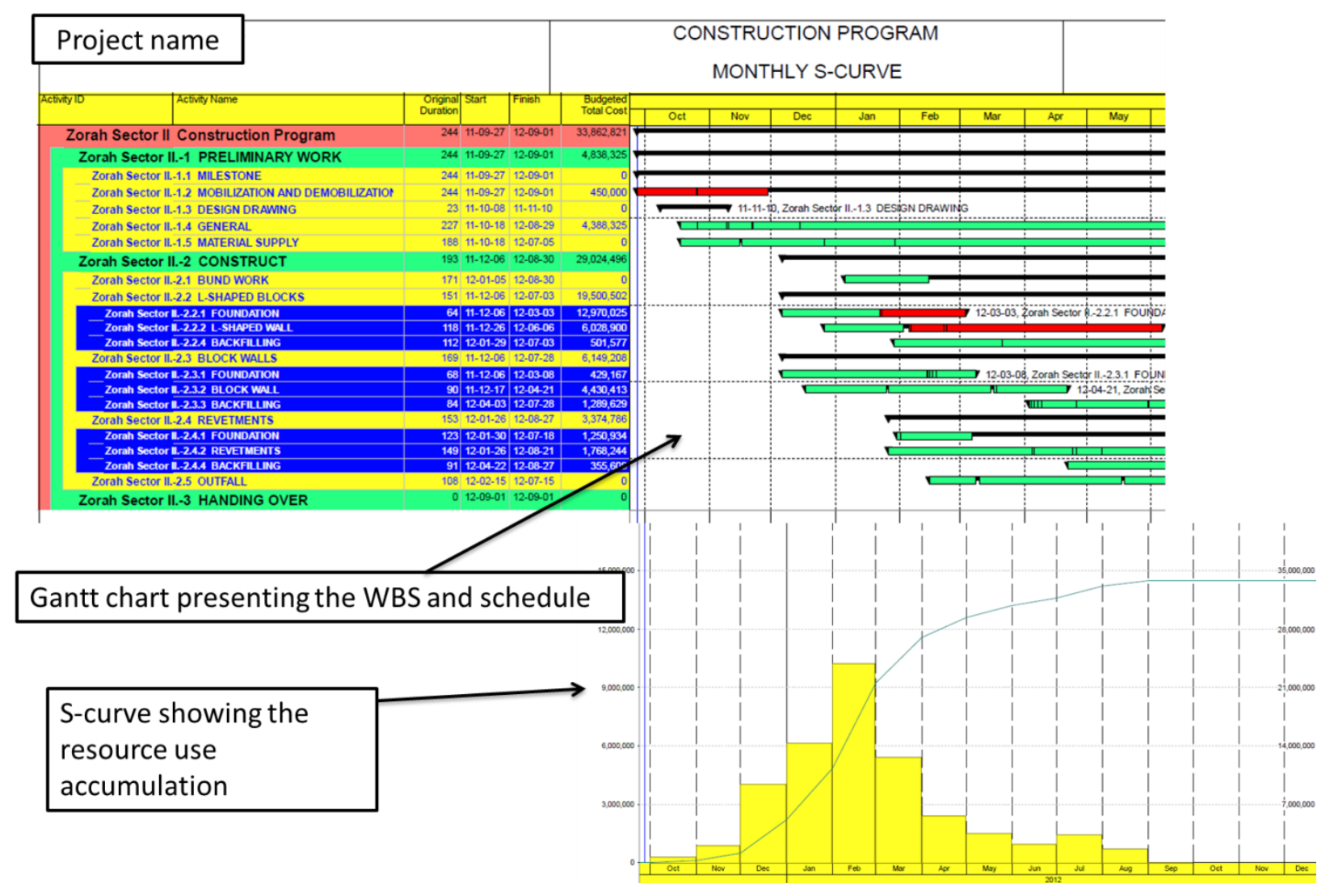

Figure 3. Project execution monitoring with Gantt chart and S-curve - an example from the construction business.

\subsection{A framework to measure performance within a project business VE}

Based on research within the scope of project-based VE performance, three metrics are identified, namely strategic, tactical and operational. These identified metrics are proposed within VE's performance framework in order to measure the overall performances of a project business VE. The generic structure of the project business VE's performance framework is presented in Figure 4.

From Figure 4, it is noticed that each of the performance metrics has several sub-metrics, which when combined contribute to measure the actual performances with a project-based VE business 
environment. For instance, the VE's strategic metric has sub-matrices such as performance on VE's resources management, performance on VE's forecasting and demand management, performance on collaborative planning and scheduling, performance on VE's production processes, performance of VE's delivery status and measurement of VE's customer satisfaction.

The second performance metric of project-based VE, tactical, consists of sub-metrics such as performance of VE's business model, performance of collaborative product development, performance of VE's marketing management, performance of VE's processes monitoring and management, performance of VE's event and risk management.

The final performance metric, operational, is also divided into sub-metrics such as performance of VE's productivity management, performance of VE's research and development management, performance of VE's waste management, performance of VE's collaborative service level, and performance of VE's operational processes efficiencies.

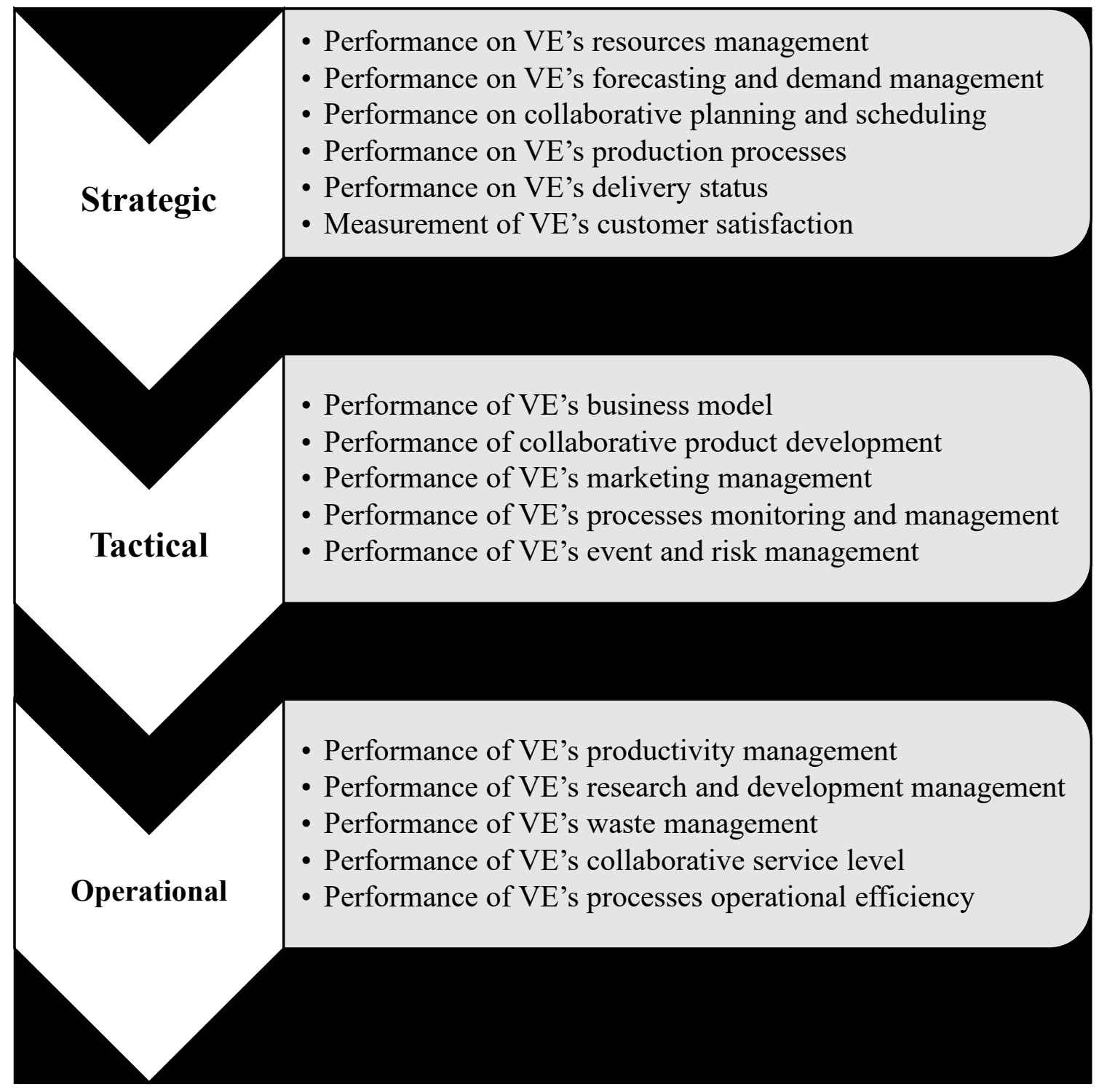

Figure 4. A framework for performance measurement within a project business virtual enterprise. 
By focusing on performance measurement within a project business VE, it is possible to obtain several benefits such as reduced labor cost, increased facility throughput and visibility of associate performance, improved morale, management skills, effectiveness and service levels. In order to manage the overall project business VE performance, it is necessary to deploy the performance metrics of each enterprise within the VE team.

All the performance metrics as outlined within this framework promote project business VE through obtaining enhanced productivity and increased visibility of production, operation and capacity planning. It is not only necessary to define the project business VE performance framework, but also to define ways to reward performance. To achieve such reward, motivation is considered the key to obtaining a high performance level. In terms of human nature, incentive programs are a way to motivate associates by rewarding them for their effort and performance.

\subsection{Performance management dimensions between project-based organization and VE}

In addition to the above-mentioned project-based VE performance metrics, specific dimensions with associated key performance indicators (KPIs) are also needed to efficiently manage the VE. Such dimensions can be characterized between the project-based organization and virtual enterprise, as highlighted in Table 3. From Table 3, it is noticed that there are nine dimensions namely, integration management, scope management, time management, cost management, quality management, human resource management, communication management, risk management and procurement management, which can be used to measure performance within a project-based organization and virtual enterprise. There are also several sub-dimensions within each of the performance management dimensions, depending on project-based organizations and virtual enterprise. For instance, in case of project-based organization, integration management has sub-dimensions, which are namely project plan, performance report and overall change control; whereas the sub-dimensions for virtual enterprise are relationship management among partners, technology integration management and performance measurement.

Table 3. Performance management dimensions with associated KPIs between project-based organization and virtual enterprise (adapted from Gunasekaran et al., 2001, Sandhu and Gunasekaran, 2004).

\begin{tabular}{|c|c|c|c|}
\hline Dimensions & Associated KPIs & $\begin{array}{l}\text { Project based } \\
\text { organization }\end{array}$ & Virtual enterprise \\
\hline $\begin{array}{l}\text { 1. Integration } \\
\text { Management }\end{array}$ & $\begin{array}{ll}\text { - } & \text { Stakeholders } \\
\text { satisfaction } \\
\text { - } & \text { Competitive } \\
\text { dimension } \\
\text { - } \text { Good } \\
\text { governance }\end{array}$ & $\begin{array}{ll}\text { - } & \text { Project plan } \\
\text { - } & \text { Performance } \\
& \text { report } \\
\text { - } & \text { Overall change } \\
\text { control }\end{array}$ & 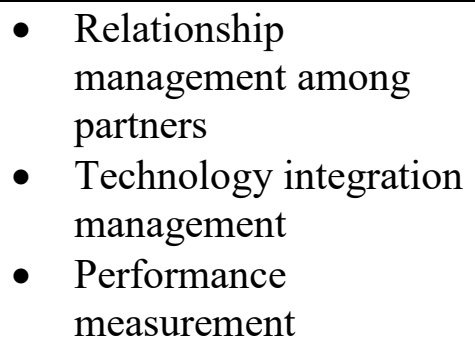 \\
\hline $\begin{array}{l}\text { 2. Scope } \\
\text { Management }\end{array}$ & $\begin{array}{ll}\text { - } & \text { Market share } \\
\text { - } & \text { Business } \\
\text { growth }\end{array}$ & $\begin{array}{ll}\text { - } & \text { Project contract } \\
\text { - } & \text { Project } \\
& \text { constraints }\end{array}$ & $\begin{array}{ll}\text { - } & \text { VE scope management } \\
\text { - } & \text { VE limitations } \\
\text { - } & \text { VE change } \\
& \text { management } \\
\end{array}$ \\
\hline
\end{tabular}




\begin{tabular}{|c|c|c|c|}
\hline & $\begin{array}{l}\text { - Net present } \\
\text { value }\end{array}$ & $\begin{array}{l}\text { - Project scope } \\
\text { change control } \\
\text { plan }\end{array}$ & \\
\hline $\begin{array}{l}\text { 3. Time } \\
\text { Management }\end{array}$ & $\begin{array}{ll}\text { - } & \text { Time-to- } \\
\text { market } \\
\text { - } & \text { Customer } \\
\text { retention } \\
\text { - } & \text { Productivity } \\
\text { improvement }\end{array}$ & 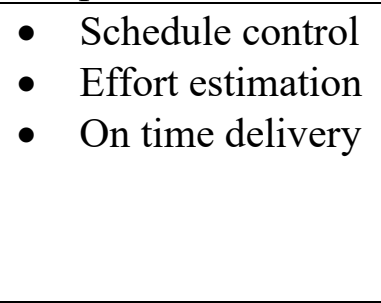 & $\begin{array}{l}\text { - } \begin{array}{l}\text { Managing production } \\
\text { schedule }\end{array} \\
\text { - Schedule assessment } \\
\text { checklist } \\
\text { - Managing to-do list }\end{array}$ \\
\hline $\begin{array}{l}\text { 4. } \text { Cost } \\
\text { Management }\end{array}$ & $\begin{array}{ll}\text { - } & \text { Cost reduction } \\
\text { - } & \text { Return on } \\
\text { investment } \\
\text { - Revenue } \\
\text { growth } \\
\end{array}$ & $\begin{array}{ll}\text { - } & \text { Cost } \\
& \text { management } \\
& \text { plan } \\
\text { - } & \text { Cost estimation } \\
\text { - } & \text { Cost control } \\
\end{array}$ & $\begin{array}{ll}\text { - } & \text { Cost estimation } \\
\text { - } & \text { Cost distribution } \\
\text { among partners } \\
\text { - Cost management } \\
\text { strategy } \\
\end{array}$ \\
\hline $\begin{array}{l}\text { 5. Quality } \\
\text { Management }\end{array}$ & $\begin{array}{ll}\text { - } & \text { Customer } \\
& \text { satisfaction } \\
\text { - } & \text { Sales volume } \\
\text { - } & \text { Production } \\
& \text { cost } \\
\text { - } & \text { Innovation } \\
& \text { level } \\
\end{array}$ & $\begin{array}{ll}\text { - } & \text { Quality } \\
\text { management } \\
\text { plan } \\
\text { - } \\
\text { Quality control } \\
\text { measurement } \\
\text { - } \text { Quality audit and } \\
\text { improvement } \\
\end{array}$ & $\begin{array}{ll}\text { - } & \text { Establishment of } \\
\text { quality within partners } \\
\text { - } & \text { Strategy for continuous } \\
\text { improvement } \\
\text { - } \\
\text { Measurement of } \\
\text { customer satisfaction }\end{array}$ \\
\hline $\begin{array}{l}\text { 6. Human } \\
\text { Resource } \\
\text { Management }\end{array}$ & $\begin{array}{l}\text { - Empowerment } \\
\text { of employee } \\
\text { - Asset } \\
\text { utilization } \\
\text { - Waste } \\
\text { management }\end{array}$ & $\begin{array}{ll}\text { - } & \text { Trust } \\
\text { management } \\
\text { - } & \text { Individual's } \\
\text { competence } \\
\text { management } \\
\text { - } \\
\text { Management of } \\
\text { well-being of } \\
\text { employees } \\
\end{array}$ & $\begin{array}{l}\text { - } \text { Management of } \\
\text { partners human capital } \\
\text { - } \\
\text { Stability in social } \\
\text { relationship } \\
\text { - } \quad \text { Knowledge-based } \\
\text { learning technique }\end{array}$ \\
\hline $\begin{array}{l}\text { 7. Communications } \\
\text { Management }\end{array}$ & $\begin{array}{ll}\text { - } & \text { Real-time } \\
\text { information } \\
\text { - } \\
\text { Information } \\
\text { security } \\
\text { - } \\
\text { Communicatio } \\
\text { n speed }\end{array}$ & 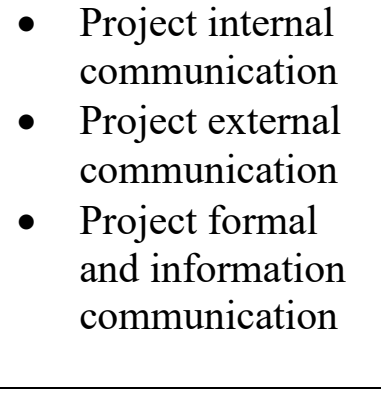 & $\begin{array}{ll}\text { - } & \text { Cloud-based } \\
\text { information sharing } \\
\text { - Level of effective } \\
\text { communication } \\
\text { between partners } \\
\text { - Managing cross } \\
\text { cultural } \\
\text { communication } \\
\end{array}$ \\
\hline $\begin{array}{ll}\text { 8. } & \text { Risk } \\
& \text { Management }\end{array}$ & 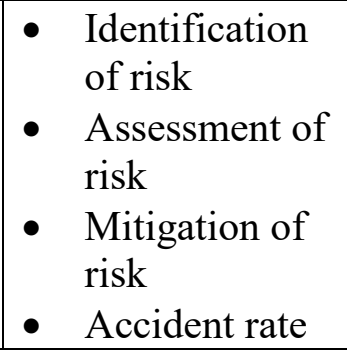 & $\begin{array}{l}\text { - } \\
\text { - } \text { Asoject risk plan } \\
\text { project risk } \\
\text { - } \\
\text { Project risk } \\
\text { monitoring and } \\
\text { control }\end{array}$ & $\begin{array}{l}\text { - Level of innovation to } \\
\text { mitigate risks } \\
\text { - Business model to } \\
\text { manage risks } \\
\text { - Risk management } \\
\text { through inter-personal } \\
\text { trust }\end{array}$ \\
\hline
\end{tabular}




\begin{tabular}{|c|c|c|c|}
\hline $\begin{array}{l}\text { 9. Procurement } \\
\text { Management }\end{array}$ & $\begin{array}{ll}\text { - } & \text { Procurement } \\
\text { time } \\
\text { - } & \text { Capital } \\
\text { investment } \\
\text { - } \\
\text { Insurance } \\
\text { management }\end{array}$ & $\begin{array}{l}\text { - Project cost/price } \\
\text { analysis } \\
\text { - Project } \\
\text { procurement } \\
\text { process } \\
\text { - Project } \\
\text { negotiation level }\end{array}$ & $\begin{array}{l}\text { - } \begin{array}{l}\text { Decentralized } \\
\text { procurement strategy }\end{array} \\
\text { - } \quad \text { Use of supplier value- } \\
\text { added services } \\
\text { - } \quad \text { Virtual procurement } \\
\text { team management }\end{array}$ \\
\hline
\end{tabular}

The associated global KPIs as presented in Table 3 for each performance management dimensions can be used to measure and manage the performances of both project-based organization and virtual enterprise level. The KPIs as used for individual organization or enterprise level can be compared with the output performance level at both the project organization level and virtual enterprise network level. The resultant performance dimensions are then being compared both at the individual and network level and necessary measures need to be taken if there are any deviations from the pre-specified performance values. Both the global and local KPIs are measured through specific methods such as weighted sum model, analytical hierarchy process, additive utility model, analytical decision model, etc., which are then compared with the pre-specified values to identify any deviations for necessary actions.

\subsection{Reference architecture for project business virtual enterprise performance measurement and management system}

The objectives to manage performance within project based organization are typically to direct control over business functions, personnel and other resources. Through performance management, project managers are able to support the needs of projects and sometimes, to coordinate business functions across various projects (e.g., technical, human, financial, resources for project bidding, communication, systems engineering, quality, and so on) (Kujala et al., 2011). It also helps project-based organization managers to mitigate or reduce both internal and external risks through sharing information either in formal or informal meetings between project team members and client and building team coherence and resources (Thiry and Deguire, 2007). On the other hand, in case of virtual enterprise, performance management dimensions filling the existing gaps concerning dynamics, mechanisms and infrastructure needed for integrated performance management in collaborative virtual enterprises. The fundamental queries about performance management in virtual enterprise are what is to be measured and how it will be measured (Ferreira et al., 2012).

In business domain whether it is project based or virtual enterprise base business model, there is a lack to explicit alignment of performance measurement and management framework among the partner organizations. In order to manage the operational processes efficiently the real-time monitoring of performance is recommended in both the business models. To measure and manage the performance, there needs two strategies, namely; establishing a measurement framework and identifying performance dimensions. The performance framework clarifies the basic requirements to set up and conduct the required measurements, while, the performance dimensions consist of items that are to be measured for assessing the performance of an organization or a business network (Camarinha-Matos et al., 2008). The performance measures enable the making of 
decisions that proactively and strategically manages the collaborative enterprise itself, whether it is project-based organization or project business virtual enterprise.

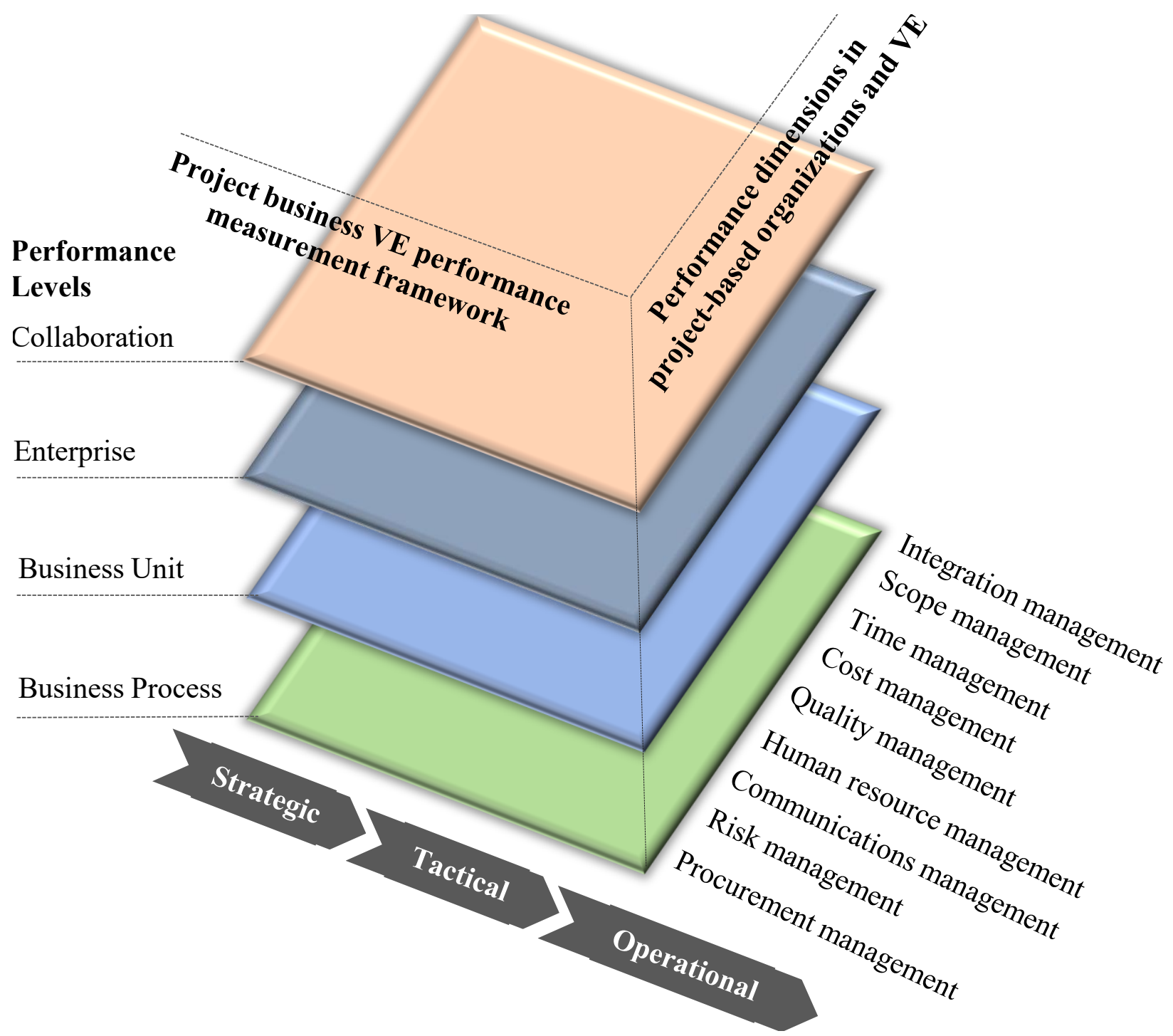

Figure 5. Reference architecture to measure performance in project business virtual enterprise.

To keep above objectives in mind this research proposed reference architecture as presented in Figure 5. From Figure 5, it is noticed that the reference framework is a combined outcomes from three performance measurement directions namely; performance levels, performance dimensions and performance measurement framework. The performance dimensions are varies depending on the performance levels which are used to measure performance on each level. In addition to, performance dimensions and levels, project business VE performances are also measured through the performance measurement framework as displayed in Figure 5. This framework is used to measure the performance on each collaboration level which is directly interfaced with various performance dimensions. This reference architecture can be used in collaborative business network to monitor and measure the performances effectively and efficiently. 


\section{Business process monitoring framework to improve project business VE management}

\subsection{Business process monitoring approaches within VE}

Business process monitoring is mainly based on a performance-based paradigm, where data from individual process is collected and analyzed. It is important to state that according to the new business performance approach, there is a change paradigm that performance measurement contribute to performance management in order to execute the business processes successfully. In the case of collaborative business process monitoring, performance management is shifted from feedback to feed forward analysis and from an individual measurement to a corporate or collaborative performance measurement (Busi and Bititci 2006).

In the case of feedback control, it is necessary to collect data to be used to analyze business performance. After analyzing the data, new or improved solutions should be designed and implemented to improve processes. The feed-forward control usually focuses on leading process monitoring and measurements that are used to take improvement actions instead of corrective actions within the business processes. This approach is considered as a predictive approach that tends to explore pro-active performance management. In order to control the collaborative business processes it is necessary to provide a proper combination of feed forward and feedback control (Busi and Bititci 2006).

The business process monitoring within the VE is defined as the real-time reporting, analysis and alerting of significant process events through collecting process data, key performance indicators and business events. Through business process monitoring tools, VE partners can identify the possible points of improvements and reengineering in each process. The business process monitoring includes methods, techniques and tools to support coordination among collaborative business processes within the VE. It can be considered as an extension of traditional workflow management systems and approaches (van der Aalst et al., 2003).

In order to gain competitive advantage, it is needed to reorganize business processes to improve business processes continuously (Kung et al., 2005). To be successful in the VE business model, it is critical to combine process modelling, process execution and process monitoring measurement at the same occasion. Most of the business process monitoring within the VE provides dashboard like user interface with the objective to visualize the process status, as well as KPIs monitoring capabilities.

\subsection{Tools used in business process monitoring: methods and approaches}

In order to perform business process monitoring several existing tools can be used, such as smart objects, cloud repository and web-based platform. In the case of smart objects, which are sensorenabled, technology and tools are used to monitor each of the processes within VE. These smart objects are integrated within the business processes and they collect required data or information continuously until the processes are at an end.

All the collected data is populated within a cloud data repository, which is an online-based data storage and retrieval system. The monitored business processes data is stored within such a cloud repository, which is eventually used to ascertain the status of any business process. By reading such stored data, it is easy to analyze it to obtain the process status. In the case of process abnormality, the VE initiator or broker company takes necessary actions to eliminate the abnormality as soon as possible. 
In addition to smart objects and cloud data repository often a web-based platform within the VE environment is used. This platform is developed within the ICT help from partner companies, which is an online platform that helps to monitor real time process information in each company within the VE network. This platform also visualizes the locations and types of risk within the network if there are any.

\subsection{Business process monitoring architectural framework}

Business process monitoring (BPM) is considered the key to the success of a VE. It plays an important role in measuring the overall performance of a VE. In the context of business collaboration, business process monitoring can be considered as one of the pioneers in predictive performance management for the collaboration context. It is a bottom-up approach designed to automate, optimize and integrate existing business processes within a VE. BPM uses modelling, workflow and application integration tools to streamline collaborative business processes and improve quality, responsiveness and customer satisfaction (Francisco et al. 2012). Its focus is on helping the VE work more effectively and efficiently.

BPM is designed to help VE focus on critical things that really drive the business value of a VE. BPM bridges the gap between strategy and execution, resulting in three major benefits for VE: improved communication, cooperation and control. BPM offers more effective communication strategy for managers and staff at all levels of the partner organization via communication framework tailored to individual roles. Due to the presence of the communication framework within a VE, it is easier for organization managers to manage more effectively and exchange ideas and information between organization levels and among business units. Such extended communication and exchange of ideas improves the VE operations in a timely manner, using up-to-date information about market conditions and operational processes.

The methodology for collaborative business process monitoring within the VE is highlighted in Figure 6. From Figure 6, it is seen that the business processes are monitored from the direct support of sensor-enabled technologies and tools (commonly known as Internet of Things). These tools can be wireless technology, radio frequency identification (RFID) tags, bar codes, QR codes, etc. Individual business process is attached with such smart sensor, which transfers real-time process information. The necessary process data from these sensors are collected through the sensors readers. All the process-monitored data is then stored within the cloud data storage, from where individual partner organization can collect its necessary process update. 


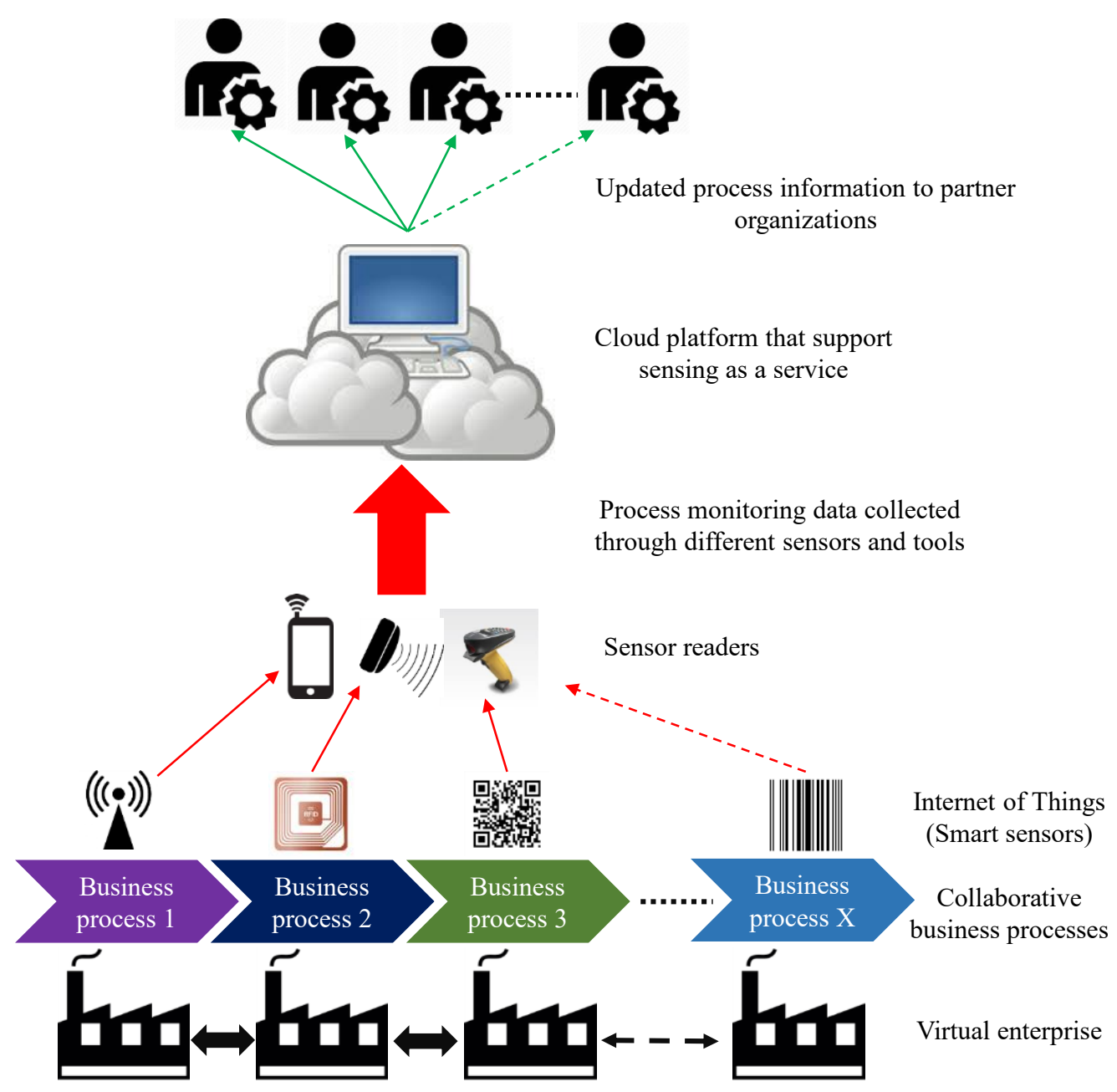

Figure 6. Methodology for collaborative business process monitoring within VE.

The data that is collected from the collaborative business processes through different sensorsenabled technologies are used to monitor and manage the VE business processes. The need to monitor VE business processes can be defined with respect to the performance level. VE performances are carried out in several stages, where each stage has its own performance metrics.

The architectural framework for VE business process monitoring is presented in Figure 7. From Figure 7 it can be seen that individual performance metrics are measured within each enterprise participating in the VE as a partner. It is generally considered that if the performance of an individual enterprise is good, it will then contribute to a better way if it participates in a VE. The overall performance of a VE is highly dependent on its collaborative enterprises. Often it may not be guaranteed that all the partners' performances are up to the mark before joining the VE. If any of the partners performance deteriorates during the VE execution it definitely affects the overall VE performance negatively. 


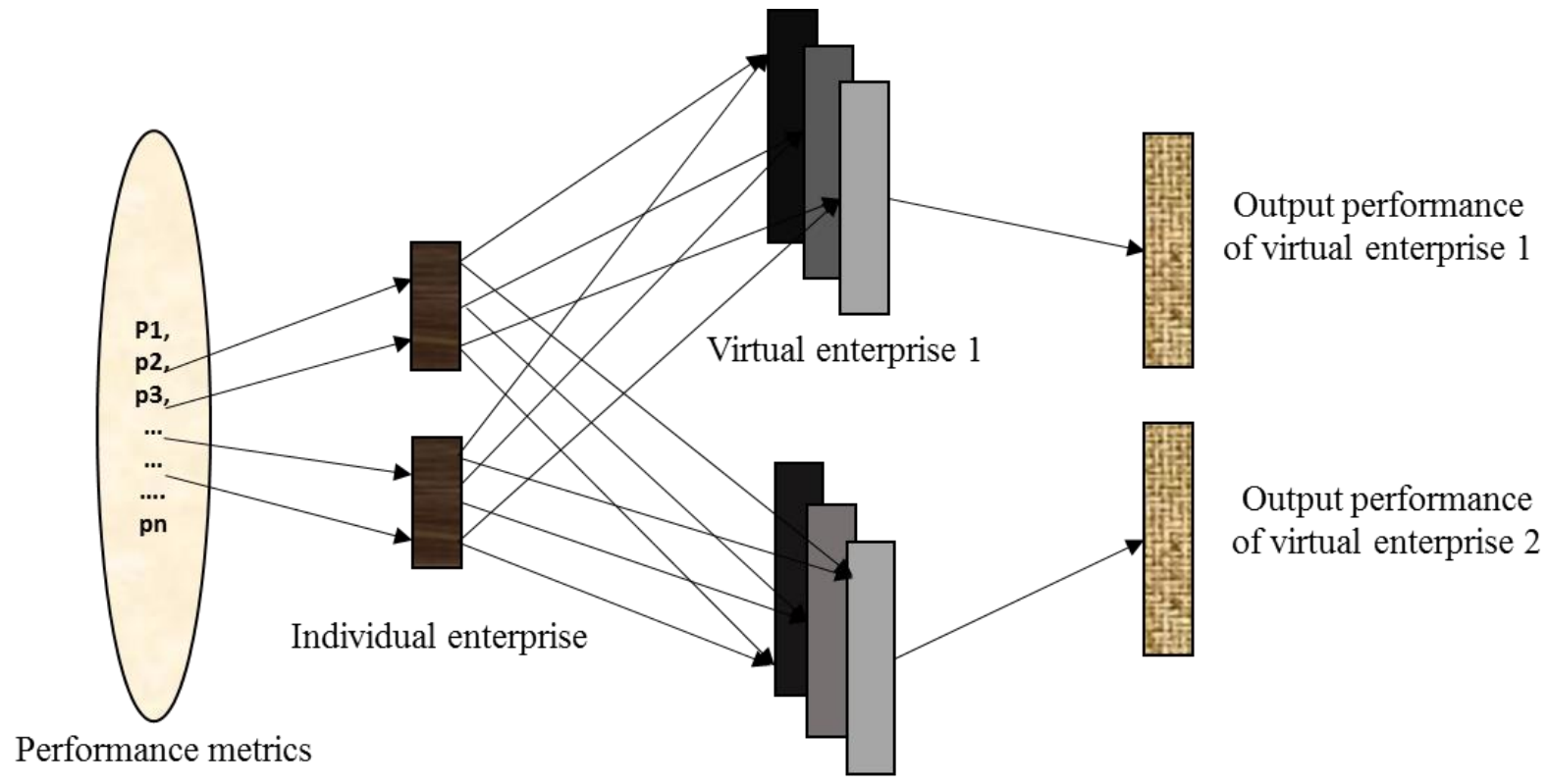

Virtual enterprise 2

Figure 7. Architectural framework for VE business process monitoring.

If each enterprise is monitored and evaluated for performance metrics, it ultimately contributes to the overall performance of the specific VE. An enterprise can participate in more than one VE, as displayed in Figure 7, where its performance will be updated to the participating VEs. Performance metrics can be different from one VE to another depending on its process-monitoring plan. The outcomes from individual VE process monitoring are used to assess the overall efficiency and effectiveness of the VE.

\section{Process monitoring within project business VE: a case implementation}

The business process monitoring within project business VE environment is implemented within a case project business VE environment. This case example is implemented in a Finnish company, which is one of the global market leaders in energy business, involves in project business delivery network. Its business processes were monitored using smart technologies such as mobile apps, web-based platform, bar codes, etc. The delivery process of the final product was monitored through the smart mobile phone as displayed in Figure 8. From Figure 8(a), it is seen that the delivery box is attached with both two dimensional QR codes and linear bar codes, which are read by the smart mobile phone to track its status update. 


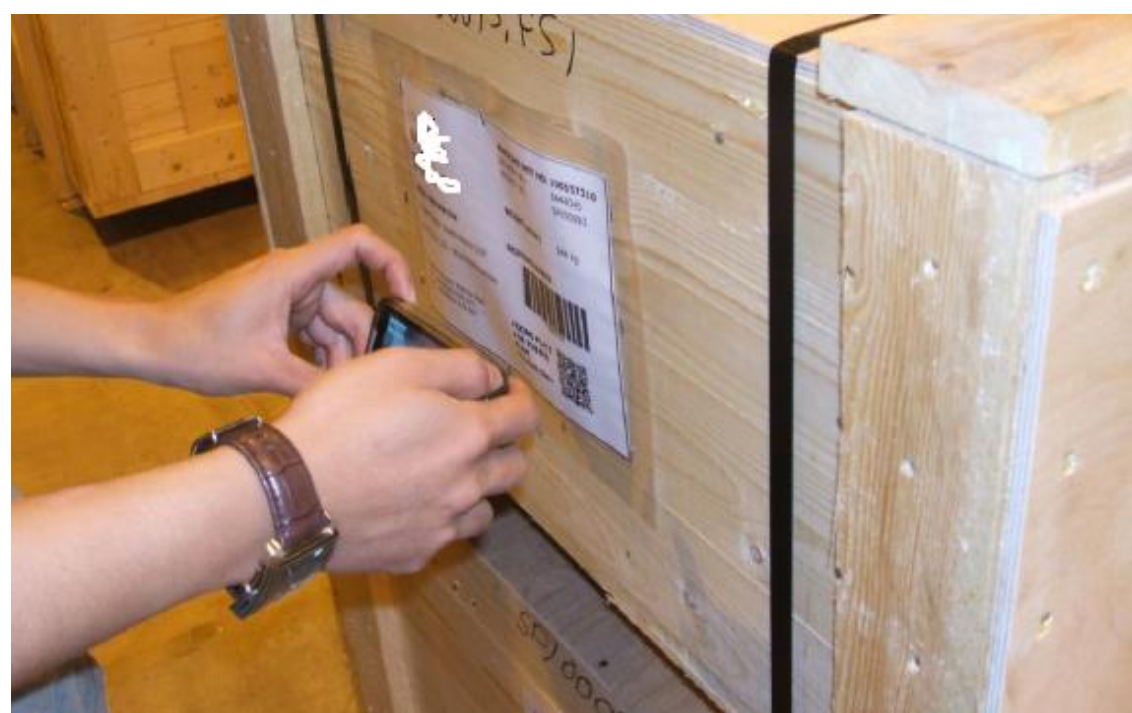

(a)

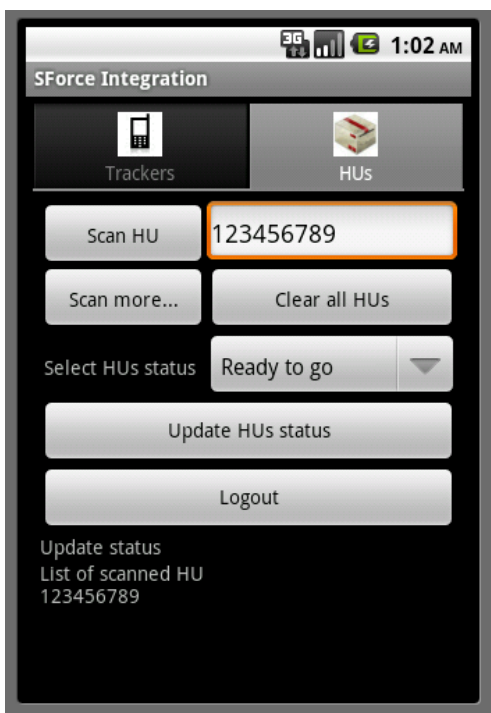

(b)

Figure 8. Case business process monitoring in a project business VE environment.

Each of the delivery box has its own handling unit (HU) number, which is scanned by the mobile phone as seen in Figure 8(b). From Figure 8(b), it is seen that necessary monitored data as collected through the mobile phone such as handling unit number, updated HUs status are displayed. This mobile phone user interface also displays reports on any quality issue of the delivery box, check materials, update site material status (receive, check), job completion information, etc.

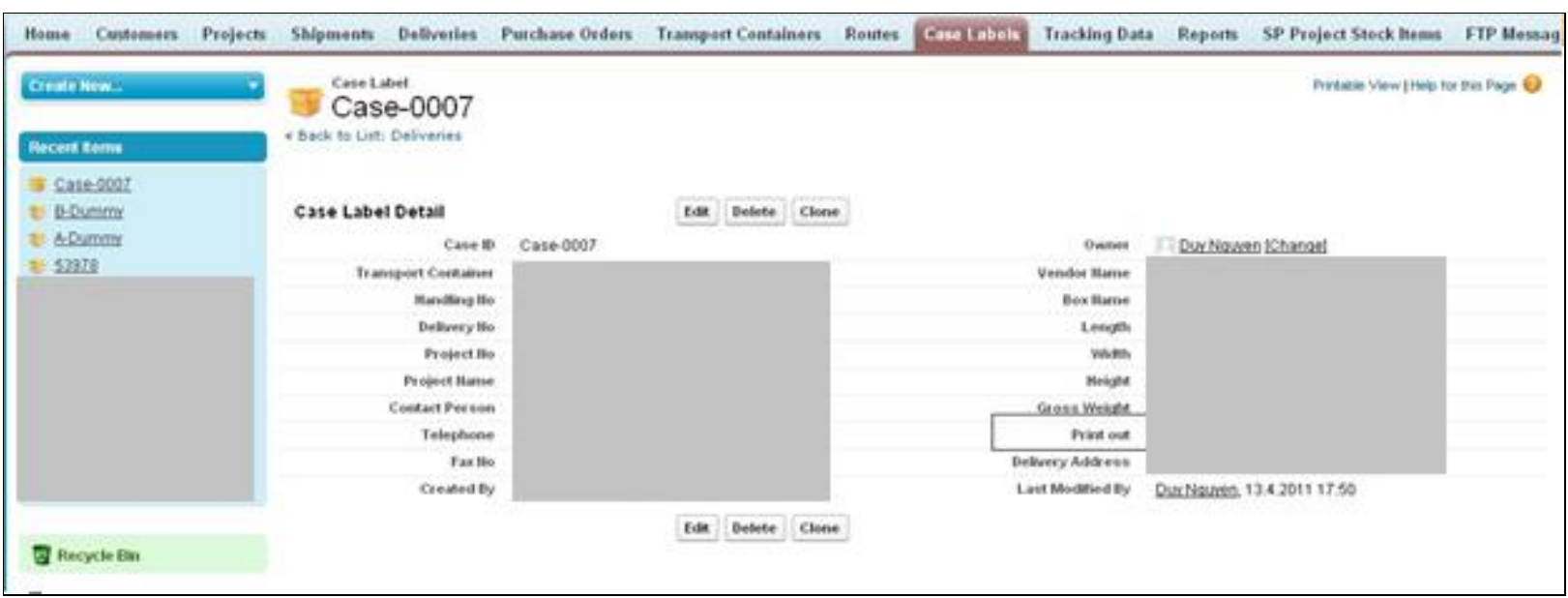

Figure 9. Web-enabled interface to display process monitored data in a project business VE.

The data as collected through the mobile phone monitoring is interfaced with the web-based platform is displayed in Figure 9. All the necessary information of the delivery process is updated on real time over the web platform. This web-based platform visualizes the necessary process status update to the user. From this platform, the users can access information related to the project number, case level number, tracking data, shipments, deliveries, etc., as displayed in Figure 9. 
The monitored information that is displayed in the web-platform is stored to the centralized project cloud data storage repository. This cloud repository is stored various project business related information or data such as project's KPIs update, progress status, costs, calendars, comparison between planned versus actual schedule, etc. All such information is stored and retrieved according to the necessity of specific information within a business case.

\section{Conclusion and future work}

Today's competitive markets require that project businesses are highly agile, effective and efficient. Agility and effectiveness are obtained by forming highly dynamic virtual enterprises within business networks. The required efficiency of creating and operating project business can only be obtained by continuous support for design, set up and enactment of virtual business networks. The concept of global manufacturing network has created benefits and opportunities for today's project businesses and it has forced projects to accept the costs of adopting global manufacturing solutions.

In addition to project business, this research work describes virtual business networks in the form of the virtual enterprise to bring interdependencies between project business and virtual enterprise. The virtual enterprise concept offers several possibilities for project businesses to manage the formulation of project organization and managing the execution of projects. Compared to traditional manufacturing industries, project organizations are more dynamic and subject to change. The virtual enterprise concept can offer several solutions for project business:

(1) Integration - inter-organizational communication and transactional relationships between the project organization

(2) Complexity - monitoring technical dependencies, task dependencies and change management

(3) Uniqueness - up-to-date product specifications shared in the project organization

(4) Timeliness - transparency of supply chains and real-time visibility to task progress

The technical implementation of these features requires the adaptation of cloud based systems and integration with existing planning systems. Such cloud-based systems provide data security and integrate inter-organizational communication between project organizations. It also maintains complex process monitoring data that is stored inside the cloud user's organization. Cloud-based systems are worked through software-as-a-service (SaaS) and platform-as-a-service (PaaS) solutions.

In this paper, the fundamental requirements such as global integration of project business operations and maintaining of virtual business networks in distributed manufacturing enterprises are defined. Collaborative project business often involves resources from various enterprises to fulfill a common objective collectively. In order to fulfill business objectives, both project businesses and virtual enterprises need to monitor and manage their business processes. The fundamental metrics to define business process performance monitoring are elaborated in this research study. The identified performance metrics can be used to measure the overall performances for both project business and virtual enterprise. A technical framework is presented with the objective of highlighting both similarities and interdependencies between project business and virtual enterprise. The fundamental metrics to define business process performance monitoring are also elaborated in this research study. The contribution to this research is that it identifies metrics, which can be applicable to measure the performance within project business VE. In addition to, a reference architecture is also introduced in this research that consists of three 
components namely, performance levels, dimensions and framework. This reference architecture can be used extensively to monitor and measure overall performance of the project business VE. In future research, the identified business process monitoring metrics will be implemented in other types of business networks in addition to project business environment. This performance monitoring system will enable the monitoring interfaces so that the status of business process instances executed outside the boundaries of the virtual enterprise project business can be tracked.

\section{References}

Afsarmanesh, H. and Camarinha-Matos, L.M., 2005. A framework for management of virtual organization breeding environments. In: Camarinha-Matos, L.M., Afsarmanesh, H. and Ortiz, A. (Eds.), Collaborative Networks and Their Breeding Environments, Springer US Publisher, 186: $35-48$.

Ajmal, M., Helo, P. and Kekäle, T., 2010. Critical factors for knowledge management in project business." Journal of Knowledge Management, 14(1): 156 - 168.

Ariyachandra, T.R. and Frolick. M.N., 2008. Critical success factors in business performance management - striving for success. Information System Management, 25(2): 113-120.

Artto, K., Davies, A., Kujala, J. and Prencipe. A., 2011. "The project business: analytical framework and research opportunities," In: Morris, P.W.G., Pinto, J. and Soderlund, J (Eds.), The Oxford Handbook of Project Management, Oxford University Press.

Artto, K. and Wikstrom, K., 2005. What is project businesses?. International Journal of Project Management, 23(5): 343-353.

Barrett, P. and Sexton, M., 2006. Innovation in small, project-based construction firms. British Journal of Management, 17(4): 331-346.

Blindenbach-Driessen, F. and Ende, J.V.D., 2010. Innovation management practices compared: the example of project-based firms. Journal of Product Innovation Management, 27(5): 705724.

Bondar, S., Ruppert. C. and Stjepandic, J., 2014. Ensuring data quality beyond change management in virtual enterprise. International Journal of Agile System Management, 7(3/4): 304-323.

Bresnen, M., Gousseyskaia, A. and Swan, J., 2004. Embedding new management knowledge in project-based organizations. Organizational Studies, 25(9): 1535-1555.

Browne, J. and Zhang, J., 1999. Extended and virtual enterprises - similarities and differences. International Journal of Agile Management Systems, 1(1): 30-36.

Bullinger, H.J., Kuhner, M. and Hoof, A.V., 2002. Analysing supply chain performance using a balanced measurement method. International Journal of Production Research, 40(15): 35333543.

Burkhardt, M.E. and Brass, D.J., 1990. "Changing patterns or patterns of change: the effects of a change in technology on social network structure and power." Administrative Science Quarterly, 35(1): 104-127.

Busi, M., and Bititci, U.S., 2006. Collaborative performance management: present gaps and future research. International Journal of Productivity and Performance Management, 55(1): 7 - 25.

Camarinha-Matos, L.M., Afsarmanesh, H. and Ollus, M., 2008. Methods and Tools for Collaborative Networked Organizations, Springer Science+Business Media LLC, New York, NY. 
Camarinha-Matos, L.M., and Abreu, A., 2007. Performance indicators for collaborative networks based on collaboration benefits. Production Planning and Control, 18(7): 592-609.

Cao, H. Folan, P., Mascolo, J. and Browne, J., 2009. RFID in product lifecycle management: a case in the automotive industry. International Journal of Computer Integrated Manufacturing, 22(7): 616-637.

Carneiro, L., Almeida, R., Azevedo, A.L., Kankaanpää, T. and Shamsuzzoha, A., 2010. An innovative framework supporting SME networks for complex product manufacturing. In: Camarinha-Matos, L.M., Boucher, X. and Afsarmanesh, H. (Eds.), Collaborative Networks for a Sustainable World (Proceedings of $11^{\text {th }}$ IFIP WG 5.5 Working Conference on Virtual Enterprises, PRO-VE 2010, Saint-Etienne, France), , Springer-Heidelberg, Germany.

Chen, D., Ducq, Y., Doumeingts, G., Zacharewicz, G. and Alix, T., 2013. A model driven approach for the modeling of services in a virtual enterprise. Zelm, M., Sanchis, R., Poler, R. and Doumeingts, G. (Eds.), Enterprise Interoperability: I-ESA'12 Proceedings.

MacCarthy, B.L. and Ramanathan, R. 2007. Recent developments in operations strategy, supply chain design and production systems virtual forms for the organization of production: a comparative analysis. International Journal of Production Economics, 110(1-2): 1-4.

Cova, B., Ghauri, P. and Salle, R., 2002. Project Marketing: Beyond Competitive Bidding, Wiley, New York, USA.

Cova, B. and Holstius, K., 1993. How to create competitive advantage in project business. Journal of Marketing Management, 9: 105-121.Davies, A. and Hobday, M. 2005. The Business of Projects: Managing Innovation in Complex Products and Systems, Cambridge University Press, Cambridge, United Kingdom.

Ferreira, F., Shamsuzzoha, A., Azevedo, A. and Helo, P., 2014. Virtual enterprise process monitoring: an approach towards predictive industrial maintenance. Progress in System Engineering, 330: 285-291.

Ferreira, P.S., Cunha, P., Shamsuzzoha, A. and Toscano, C., 2012. Framework for performance measurement and management in a collaborative business environment. International Journal of Productivity and Performance Management, 61(6): 672-690.

Feser, E.J. and Bergman, E.M., 2000. National industry cluster templates: a framework for applied regional cluster analysis. Regional Studies, 34(1): 1-19.

Francisco, R.P., Azevedo, A. and Almeida, A., 2012. Alignment prediction in collaborative networks. Journal of Manufacturing Technology Management, 23(8): 1038 - 1056.

Fulk, J., Schmitz, J. and Steinfield, C. W., 1990. "A social influence model of technology use. In: J.Fulk \& C. W.Steinfield (Eds.), Organizations and communication technology, Sage Publisher, Newbury Park, CA, 117-140.

Goranson, H.T., 2003. Virtual enterprise management architectural support for the advanced virtual enterprise. Computer in Industry, 51(2): 113-125.

Gossain, S. and Kandiah, G., 1998. Reinventing value: the new business ecosystem. Strategy \& Leadership, 26(5): 28-33.

Gunasekaran, A., Patel, C. and Tirtiroglu, E., 2001. Performance measures and metrics in a supply chain environment. International Journal of Operations and Production Management, 21: 7187.

Gustafsson, M. Smyth, H.J., Ganskau, E. and Arhippainen, T., 2009. Managing trust: bridging strategic and operational issues for project business. K. Kähkönen, A.S. Kazi, M. Rekola (Eds.), The Human Side of Projects in Modern Business. IPMA Scientific Research Paper Series, Project Management Association and VTT, Helsinki. 
Hadijkhani, A., 1996. Project marketing and the management of discontinuity. International Business Review, 5(3): 319-336.

Han, J., Lee, S-H. and Nyamsuren, P., 2015. An integrated engineering change management process model for a project-based manufacturing. International Journal of Computer Integrated Manufacturing, 28(7): 745-752.

Harmon, P., 2015. The scope and evolution of business process management. In: Brocke, J.Y. and Rosemann, M. (Eds.), Handbook on Bus. Process Manage, Part I, 37-80.

Harrington, H.J., 1991. Business Process Improvement: The Breakthrough Strategy for Total Quality, Productivity and Competitiveness, McGraw-Hill, New York, NY.

Hellström, M., 2005. Business concepts based on modularity. Abo Akademi University Press. Doctoral thesis.

Hobday, M., 2000. The project-based organization: an ideal form for managing complex products and systems?. Research Policy, 29(7-8): 871-893.

Holmes, A., 2001. Failsafe IS project delivery, Gower Publishing Limited, Aldershot, UK.

Holstius, K., 1989. Project business as a strategic choice. A theoretical and empirical study of project marketing. Research papers, Lappeenranta University of Technology, Finland.

Jain, S., Choong, N.F., Aye, K.M. and Luo, M., 2001. Virtual factory: an integrated approach to manufacturing systems modeling. International Journal of Operations \& Production Management, 21(5/6): 594-608.

Kochhar, A., and Y. Zhang. 2002. A framework for performance measurement in virtual enterprises. Proceedings of 2nd International Conference on Work Performance Measurement, Hanover, 2-11.

Kujala, S., Artto, K., Aaltonen, P. and Turkulainen. V., 2009. Business models in project-based firms - towards a typology of solution-specific models. International Journal of Project Management, 28(2): 117-129.

Kujala, J., Artto, K. and Parhankangas, A., 2011. Factors influencing design and performance of the business model of a project-based firm. International Journal of Project Management, 28(9):960-970.

Kujala, J., Ahola, T., Westerholm, T., Lehtonen, M., Laitinen, E. and Artto, K., 2007. Performance measurement in project business networks. Proceedings of the 8th International Conference of the International Research Network on Organising by Projects, Brighton, UK.

Kung, P., Hagen, C., Rodel, M. and Seifert, S., 2005. Business process monitoring \& measurement in a large bank: challenges and slected approaches. Proceedings of $16^{\text {th }}$ International Workshop on Database and Expert Systems Applications (DEXA'05), 22-26 August, Copenhagen, Denmark, 955-961.

Lescure, M., Shaw, N. and Chapman, G. 2001. Performance measurement in organizational networks: an exploratory case study. International Journal of Business Performance Management, 38(1): 30-46.

Li, Q., Wang, Z-y., Cao, Z-c., Du, R-y. and Luo, H., 2015. Process and data fragmentation-oriented enterprise network integration with collaboration modelling and collaboration agents. Enterprise Information System, 9(5-6): 468-498.

Lundin, R.A. and Steinthórsson, R.S., 2003. "Studying organizations as temporary." Scandinavian Journal of Management, 19 (2): 233-250.

Lycett, M., Rassau, A. and Danson, J., 2004. Programme management: a critical review. International Journal of Project Management, 22(45): 289-299. 
McDonough III, E.F. and Spital, F.C., 2003. Managing project portfolios. Research in Technology Management, 46(3): 40-46.

Molina, A., Velandia, M. and Galeano, N., 2007. Virtual enterprise brokerage: a structure-driven strategy to achieve build to order supply chains. International Journal of Production Research, 45(17): 3853-3880.

Morris, P.W.G., 1994. The Management of Projects. Thomas Telford, London, OK.

Mowshowitz, A., 1994. Virtual organization: a vision of management in the information age. The Information Society: An International Journal, 10(4): 267-288.

Ouzizi , L., Anciaux, D., Portmann, M.C. and Vernadat, F., 2006. A model for cooperative planning within a virtual enterprise. International Journal of Computer Integrated Manufacturing, 19(03): 197-209.

Panetto, H., and Cecil, J., 2013. Information systems for enterprise integration, interoperability and networking: theory and applications. Enterprise Information System, 7(1): 1-6.

Prencipe, A. and Tell F., 2001. Inter-project learning: processes and outcomes of knowledge codification in project-based firms. Research Policy, 30(9): 1373-1394.

Romero, D. and Molina, A., 2010. Virtual organization breeding environments toolkit: reference model, management framework and instantiation methodology. Production Planning \& Control: The Management of Operations, 21(2): 181-217.

Saiz, J.J.A., Rodriguez, R. and Bas, A.O., 2005. A performance measurement system for virtual and extended enterprises. In: Camarinha-Matos, L.M., Afsarmanesh, H. and Ortiz, A. (Eds.), Collaborative Networks and Their Breeding Environments, Springer US Publisher, 186: 285292.

Sandhu, M.A. and Gunasekaran, A., 2004. Business process development in project-based industry: a case study. Business Process Management Journal, 10(6): 673- 690.

Schulte, S., Schuller, D., Steinmetz, R. and Abels, S., 2012. Plug-and-play virtual factories. IEEE Internet Computing, 16(5): 78-82.

Shamsuzzoha, A., Kankaanpää, T., Carneiro, L. and Almeida, R., 2012. Methodological support to establish collaborative non-hierarchical virtual enterprises for complex product manufacturing. International Journal of Networking and Virtual Organisation, 11 (3/4): 363381.

Shenhar, A.J. and Dvir, D., 2004. Project management evolution: past history and future research directions. Slevin, D.P., Cleland, D.I. and Pinto, J.K. (Eds.), Proceedings of the PMI Research Conference, London, UK, 11-14 July. Project Management Institute, Pennsylvania, USA.

Thiry, M. and Deguire, M., 2007. Recent developments in project-based organisations. International Journal of Project Management, 25(7): 649-658.

Tikkanen, H., Kujala, J. and Artto, K., 2007. The marketing strategy of a project-based firm: the four portfolios framework. Industrial Marketing Management, 36(2): 194-205.

Tinnilä, M., 1995. "Strategic perspective to business process redesign", Business Process Reengineering \& Management Journal, 1(1): 44 - 59.

Turner, J.R. and Keegan, A., 2001. Mechanisms of governance in the project-based organization: roles of the broker and steward. European Management Journal, 19 (3): 254-267.

Uzzi, B., 1997. "Social structure and competition in interim networks: the paradox of embeddedness." Administrative Science Quarterly, 42(1): 35-67.Valilai, O.F. and Houshmand, M., 2014. A platform for optimisation in distributed manufacturing enterprises based on cloud 
manufacturing paradigm. International Journal of Computer Integrated Manufacturing, 27(11): 1031-1054.

van der Aalst. W.M.P., Hofstede, A.H.M. and Weske, M., 2003. Business process management: a survey. In: van der Aalst. W.M.P., Hofstede, A.H.M. and Weske, M. (Eds.), Business Process Management, Springer, Berlin Publisher, 2678: 1-12.

Varela, M. L., Putnik, G. D. and Cruz-Cunha, M.M., 2012. Web-based technologies integration for distributed manufacturing scheduling in a virtual enterprise. International Journal of Web Portals (IJWP), 4(2): 19-34.

Vergidis, K. Turner, C., Alechnovic, A. and Tiwari, A., 2015. An automated optimisation framework for the development of re-configurable business processes: a web services approach. International Journal of Project Management, 28(1): 41-58.

Whitley, R., 2006. Project-based firms: new organizational form or variations on a theme? Industrial Corporate Change, 15(1): 77-99.

Wikstrom, K., Artto, K., Kujala, J. and Soderlund, J., 2010. Business models in project business. International Journal of Project Management, 28(8): 832-841.

Xue, X., Shen, Q. and Ren, Z., 2010. Critical review of collaborative working in construction projects: business environment and human behaviors. Journal of Management Engineering, 196-208.

Yang, X., Malak, R.C., Lauer, C., Weidig, C., Hagen, H., Hamann, B., Aurich, J.C. and Kreylos, O., 2015. Manufacturing system design with virtual factory tools. International Journal of Computer Integrated Manufacturing, 28(1): 25-40.

Zhang, W., Zhang, S., Cai, M. and Jian, W., 2015. An agent-based peer-to-peer architecture for semantic discovery of manufacturing services across virtual enterprises. Enterprise Information System, 9(3): 233-256.

Zhou, Y. and Chen, Y., 2008. Project-oriented resource assignment: from business process modelling to business process instantiation with operational performance consideration. International Journal of Computer Integrated Manufacturing, 21(1): 97-110. 